\title{
Literature Riview : Efektivitas Terapi Rendam Kaki Hangat Dengan Pengobatan Standar Untuk Menurunkan Tekanan Darah Pada Lansia
}

\author{
Nadia Dwi Tiara ${ }^{1 *}$, Benny Arief Sulistyanto ${ }^{2}$, Firman Faradisi ${ }^{3}$ \\ 1,2,3Program Studi Diploma Tiga Keperawatan Fakultas Ilmu Kesehatan, Universitas Muhammadiyah \\ Pekajangan Pekalongan, Indonesia \\ *email: nadiatiara2300@gmail.com
}

\begin{abstract}
Hypertension could be manage by pharmacological and non-pharmacological therapy. One of the non-pharmacological therapies is warm foot bath therapy. The study aimed to examine the effectiveness of warm foot bath therapy in decreasing blood pressure among elderly with hypertension. The study was applied a literature review. There are three articles reviewed that obtained from PUBMED and GARUDA databases. The keyword has been used is "hypertension", warm foot bath therapy" and "blood pressure". The articles involved was published in $2015-2017$. The results showed that there was no significant difference between warm foot bath therapy and standard treatment. As the conclusion, warm foot bath therapy and standard treatment are equally effective in decreasing blood pressure among hypertension patients.
\end{abstract}

Keywords: blood pressure; hypertension; warm foot bath therapy

\section{Abstrak}

Hipertensi dapat menggunakan terapi farmakologi dan nonfarmakologi salah satu terapi non farmakologi untuk penatalaksanaan hipertensi adalah terapi rendam kaki air hangat. Tujuan: Penelitian ini bertujuan untuk mengetahui perbedaan efektivitas penggunaan pengobatan standard dengan rendam kaki air hangat. Desain karya tulis ilmiah berupa literature review dengan jumlah tiga jurnal yang diambil dari pubmed dan garuda dengan kata kunci "hipertensi", "rendam kaki air hangat" dan "tekanan darah" terbit tahun 2015 - 2017. Analisa penelitian menunjukkan tidak ada perbedaan bermakna antara terapi rendam kaki air hangat dengan pengobatan standar. Pemberian terapi rendam kaki air hangat dan pengobatan standard sama-sama efektif dalam menurunkan tekanan darah.

Kata kunci: Hipertensi; rendam kaki air hangat; tekanan darah

\section{Pendahuluan}

Hipertensi adalah keadaan dimana peningkatan tekanan darah secara terus menerus pada beberapa kali pemeriksaan yang diakibatkan oleh satu faktor atau beberapa faktor resiko lain yang tidak berjalan dengan baik untuk mempertahankan tekanan darah secara normal, Menurut WHO (World Health Organization), batas normal tekanan darah sistolik $120-140 \mathrm{mmHg}$ dan batas normal tekanan diastolik 80 $90 \mathrm{mmHg}$, Secara umum, seseorang bias dikatakan menderita hipertensi apabila tekanan darah melebihi 140/90 mmHg [1].

Hipertensi sekarang jadi masalah utama kita semua, tidak hanya di Indonesia tapi juga di dunia, karena hipertensi ini merupakan salah satu factor resiko penyakit seperti jantung, gagal ginjal, stroke, Menurut Organisasi kesehatan dunia (World Health Organization) tahun 2019 prevalensi hipertensi secara global besar sebanyak (22\%) dari total penduduk dunia. Dari sebanyak penderita tersebut, banyak berkurang 


\section{Prosiding Seminar Nasional Kesehatan Lembaga Penelitian dan Pengabdian Masyarakat Universitas Muhammadiyah Pekajangan Pekalongan}

seperlima yang melakukan upaya penanganan terhadap tekanan darah yang dimiliki. Prevalensi wilayah Afrika prevalensi hipertensi tertinggi sebesar (27\%). Di Asia Tenggara menduduki posisi ke-3 tertinggi dengan prevalensi sebesar (25\%) terhadap total penduduk, WHO juga memprediksi satu diantara lima perempuan di seluruh dunia menderita hipertensi, Jumlah ini lebih besar dari laki-laki yaitu satu diantara empat, factor usia adalah salah satu factor yang paling berpengaruh terhadap kejadian, Semakin bertambahnya umur semakin tinggi mendapatkan resiko hipertensi karena adanya perubahan alamiah didalam tubuh yang mempengaruhi pembuluh darah, jantung, dan hormone [2]. Dalam perkembangan lansia, terjadi penurunan fungsi tubuh diakibatkan karna proses penuaan salah satunya terjadi system penurunan kekebalan tubuh contohnya gangguan kesehatan yang paling banyak dialami oleh lansia pada system kardiovaskuler dan penurunan fungsi organ serta mengalami perubahan tekanan darah oleh sebab itu, lansia dianjurkan untuk memeriksakan tekanan darah secara teratur agar dapat mencegah hipertensi [3].

Penatalaksanaan hipertensi terbagi dua yaitu, terapi farmakologis dan terapi nonfarmakologis, Terapi farmakologi pada penderita hipertensi dapat berupa ACE inhibitor, Penyakat kanal kalsium, beta bloker, dan diuretic. Sedangkan pengobatan hipertensi secara non-farmakologis, dapat dilakukan dengan mengubah gaya hidup yang lebih sehat, seperti olah raga, diet sehat, berhenti merokok, mengurangi asupan garam, dll [4].

lansia mempunyai tingkat kepatuhan terhadap pengobatan farmakologis yang rendah yaitu 47\% (95\% CI: 41\%-53\%), Selain itu, ketidakmampuan lansia untuk kembali untuk berobat karena penurunan kemampuan fisik juga menjadi salah satu penyebab ketidakpatuhan lansia terhadap pengobatan hipertensi (refensi), Oleh karena itu, terapi alternative non farmakologi perlu juga diberikan pada lansia yang dapat dilakukan secara mandiri oleh lansia di rumah untuk mengontrol tekanan darah [5].

Salah satu terapi non farmakologi yang dapat dilakukan adalah dengan terapi rendam kaki dengan air hangat yang bertemperatur 38-40 $C$ [6]. and [7].[8], Masi, and [9]. Secara ilmiah air hangat memiliki dampak fisiologis terhadap tubuh, yaitu berdampak pada pembuluh darah. Air hangat membantu sirkulasi darah menjadi lancar, serta menguatkan otot-otot dan ligament yang mempengaruhi sendi tubuh [10].dikutipdari [11].

Rendam kaki dengan air hangat selain mampu menurukan tekanan darah, terapi rendam kaki dengan air hangat juga mampu untuk meringankan nyeri sendi, menurunkan tegangan otot, membunuh kuman, menghilangkan bau kaki, dan meningkatkan kualitas tidur, Melihat dari indikasinya terapi rendam kaki dengan air hangat ini juga bias dilakukan untuk lansia, selain mampu untuk menurunkan tekanan darah pada lansia penderita hipertensi, rendam kaki hangat ini juga mampu untuk meningkatkan kualitas tidur yang biasanya juga terjadi pada lansia, Manfaat lain dari terapi rendam kaki dengan air hangat adalah efek fisik panas/hangat yang dapat menyebabkan zat cair, padat dan gas mengalami pemuaian kesegala arah dan dapat meningkatkan reaksi kimia, Pada jaringan akan terjadi peningkatan metabolisme pertukaran antara zat kimia tubuh dengan cairan dalam tubuh, Air hangat / panas memiliki efek biologis yang dapat menyebabkan dilatasi pembuluh darah yang 


\section{Prosiding Seminar Nasional Kesehatan Lembaga Penelitian dan Pengabdian Masyarakat Universitas Muhammadiyah Pekajangan Pekalongan}

mengakibatkan peningkatan sirkulasi darah meningkat, Berdasarkan latar belakang diatas peneliti tertarik untuk mengetahui bagaimana efektifitas terapi rendam kaki dengan air hangat pada penurunan tekanan darah lansia. Tujuan penelitian ini untuk mengetahui efektifitas terapi rendam kaki menggunakan air hangat terhadap penurunan tekanan darah pada usia lanjut [12].

\section{Literature review}

Salah satu upaya yang bias dilakukan untuk menurunkan atau mengontrol tekanan darah yaitu Hidroterapi (hydrotherapy) metode pengobatan menggunakan air untuk mengobati atau meringankan kondisi yang menyakitkan dan merupakan metode terapi dengan pendekatan "lowtech" yang mengandalkan pada respon-respon tubuh terhadap air. Rendam kaki air hangat merupakan salah satu terapi komplementer yang bisa menurunkan tekanan darah.

Maka dari itu diberikan terapi rendam kaki menggunakan air hangat untuk terapi non farmakologis dalam menurukan tekanan darah, yang mana terapi rendam kaki menggunakan air hangat inipun mudah dilakukan dan dapat diberikan pada berbagai jenis golongan lanjut usia. Terapi non-farmakologis dengan metode ini lebih mudah karena menggunakan air hangat yang bias dilakukan di rumah, tidak membutuhkan biaya yang mahal, dan tidak memiliki efek samping yang berbahaya, air hangat berdampak fisiologis bagi tubuh terutama pada pembuluh darah, dimana hangatnya air membuat sirkulasi darah menjadil ancar. Air hangat juga mampu menguatkan otot-otot dan ligamen yang mempengaruhi sendi-sendi tubuh. Merendam kaki dalam air hangat yang bertemperatur $37^{\circ}-39^{\circ} \mathrm{C}$ bermanfaat dalam menurunkan kontraksi otot sehingga menimbulkan perasaan rileks yang bisa menstabilkan kerja jantung dan melancarkan aliran darah sehingga dapat menurunkan tekanan darah karena terapi air hangat merupakan salah satu jenis terapi alamiah yang bertujuan untuk meningkatkan sirkulasi darah, meningkatkan relaksasi otot, menyehatkan jantung, menghilangkan stres, meringankan rasa sakit, meningkatkan permeabilitas kapiler, memberikan kehangatan pada tubuh sehingga sangat bermanfaat untuk terapi penurunan tekanan darah pada hipertensi [13].

Pada tekanan diastole keadaan di dalam ventrikel turun drastik dan aliran darah menjadi lancar dengan adanya pelebaran pembuluh darah dapat menurunkan tekanan darah diastolik. Dalam hal ini, terapi air hangat dapat mengurangi tahanan perifer. Penurunan tekanan darah juga dapat terjadi akibat berkurangnya aktivitas jantung memompa darah. Peningkatan efisiensi kerja jantung dicerminkan dengan penurunan tekanan darah sedangkan penurunan tahanan perifer dicerminkan dengan penurunan tekanan diastolik. Secara psikologis respon tubuh terhadap air hangat dimana terjadi perpindahan hangatnya air ketubuh dapat menghilangkan stress, kegelisahan, depresi, kecemasan sehingga membuat perasaan menjadi rileks, tenang dan nyaman [14].

\section{Metode}

Rancangan karya tulis ilmiah ini menggunakan metode Literatur Review. Jurnal yang digunakan dalam literature review didapatkan melalui database PubMed untuk 


\section{Prosiding Seminar Nasional Kesehatan Lembaga Penelitian dan Pengabdian Masyarakat Universitas Muhammadiyah Pekajangan Pekalongan}

literature berbahasa inggris dan Garuda untuk artikel berbahasa Indonesia peneliti juga menggunakan google scholar sebagai metode pencarian yang lebih luas dengan memasukkan kata kuncidari PICO yaitu "hipertensi, "rendam kaki air hangat" dan "tekanan darah". Kata kunci tersebut digunakan sebagai strategi pencarian literature. Artikel yang muncul disetiap data base akan diidentifikasi dengan kriteria inklusi dan ekslusi hingga menemukan artikel yang tepat. Pengumpulan artikel akan di telaah dengan matriks untuk mengorganisir dan membandingkan artikel-artikel yang sesuai dengan criteria inklusi dan eksklusi.

\section{Hasil dan Pembahasan}

\section{Hasil}

Penelitian yang dilakukan menggunakan literature review menunjukkan bahwa rata-rata (33,33\%) dipublikasikan pada tahun 2015, 2016 dan 2017, dengan keseluruhan menggunakan desain penelitian Pre Experiment sebesar (66,67\%). Dan sampling penelitian diatas menunjukkan keseluruhan menggunakan Purporsive Sampling sebanyak (100\%), sebagian instrumen penelitian menggunakan Sphygmanometer dan stetoskop sebanyak $(66,67 \%)$, dan hampir keseluruhan analisa statistik dalam penelitian menggunakan Uji Wilcoxon sebanyak (66,67\%).

\section{Analisis Terapi Rendam Kaki Menggunakan Air Hangat}

Secara umum, terapi rendam kaki menggunakan air hangat dapat menurunkan tekanan darah baik tekanan sistolik maupun diastolik. Adapun rincian berdasarkan dari ketiga jurnal tersebut yaitu :

Tabel 3.1 Analisis Terapi Rendam Kaki Menggunakan Air Hangat

\begin{tabular}{ccc|cc}
\hline \multirow{2}{*}{ Artikel } & \multicolumn{2}{c|}{ Sistolik } & \multicolumn{2}{c}{ Diastolik } \\
\cline { 2 - 5 } & Pre & Post & Pre & Post \\
\hline Santoso,2015 & 158,5 & 148,19 & 95 & 89,75 \\
\hline Likafah,2016 & 150,29 & 140,88 & 98,26 & 89,25 \\
\hline Hanani\& Axmalia,2017 & 183 & 147 & 96,5 & 74 \\
\hline Rata-Rata & 163,93 & 145,36 & 96,59 & 84,33 \\
\hline
\end{tabular}

Tabel 3.2 Nilai Rata-Rata Pengaruh Terapi pada Tekanan Darah Sistolik dan Diastolik

\begin{tabular}{|c|c|c|c|c|c|c|}
\hline & \multicolumn{3}{|c|}{ Sistolik } & \multicolumn{3}{|c|}{ Diastolik } \\
\hline & Pre & Post & Total & Pre & Post & Total \\
\hline $\begin{array}{c}\text { AirHangat/Hydrot } \\
\text { herapy }\end{array}$ & $\begin{array}{c}\text { (a) } \\
163,93\end{array}$ & $\begin{array}{c}\text { (b) } \\
145,36\end{array}$ & $\begin{array}{c}(a+b) \\
309,29\end{array}$ & $\begin{array}{c}\text { (a) } \\
96,59\end{array}$ & $\begin{array}{c}\text { (b) } \\
84,33\end{array}$ & $\begin{array}{c}(a+b) \\
180,92\end{array}$ \\
\hline $\begin{array}{c}\text { Pengobatanstand } \\
\text { ar }\end{array}$ & $\begin{array}{l}\text { (c) } \\
152\end{array}$ & $\begin{array}{c}\text { (d) } \\
141,43\end{array}$ & $\begin{array}{c}(c+d) \\
293,43\end{array}$ & $\begin{array}{l}\text { (c) } \\
93\end{array}$ & $\begin{array}{l}(\text { H) } \\
82,3\end{array}$ & $\begin{array}{l}(c+d) \\
175,3\end{array}$ \\
\hline Total & $\begin{array}{c}(a+c) \\
315,93\end{array}$ & $\begin{array}{c}(b+d) \\
286,79\end{array}$ & $\begin{array}{c}(a+b+c+ \\
d) \\
602,72\end{array}$ & $\begin{array}{c}(a+c) \\
189,59\end{array}$ & $\begin{array}{c}(b+d) \\
166,63\end{array}$ & $\begin{array}{c}(a+b+c \\
+d) \\
356,22\end{array}$ \\
\hline
\end{tabular}




\section{Prosiding Seminar Nasional Kesehatan Lembaga Penelitian dan Pengabdian Masyarakat Universitas Muhammadiyah Pekajangan Pekalongan}

Berdasarkan tabel diatas hasil pengukuran tekanan darah pada terapi rendam kaki air hangat / hydrotherapy didapatkan hasil perhitungan efektivitas intervensi terapi rendam kaki air hangat dengan obat farmakologis untuk menurunkan tekanan darah. Hasil dari penghitungan Effect Clinical Meassure dari tekanan darah pada sistolik dan diastolic didapatkan hasil $\mathrm{OR}=1$ yang artinya tidak terdapat perbedaan antara terapi rendam kaki air hangat dengan pengobatan standar. Begitu juga Rasio Risk berdasarkan hasil dari penghitungan dari tekanan darah pada sistolik dan diastolic didapatkan hasil $\mathrm{RR}=1$ berarti terapi rendam kaki air hangat tidak mempunyai efek atau tidak lebih baik untuk menurunkan tekanan darah dibandingkan dengan pengobatan standar.

\section{Pembahasan}

Salah satu upaya yang bias dilakukan untuk menurunkan atau mengontrol tekanan darah dengan terapi rendam kaki air hangat. Secara ilmiah air hangat berdampak fisiologis bagi tubuh terutama pada pembuluh darah, dimana hangatnya air membuat sirkulasi darah menjadi lancar. Air hangat juga mampu menguatkan otot-otot dan ligamen yang mempengaruhi sendi-sendi tubuh. Merendam kaki dalam air hangat yang bertemperatur $37^{\circ}-39^{\circ} \mathrm{C}$ bermanfaat dalam menurunkan kontraksi otot sehingga menimbulkan perasaan rileks yang bias menstabilkan kerja jantung dan melancarkan aliran darah sehingga dapat menurunkan tekanan darah karena terapi air hangat merupakan salah satu jenis terapi alamiah yang bertujuan untuk meningkatkan sirkulasi darah, meningkatkan relaksasi otot, menyehatkan jantung, menghilangkan stres, meringankan rasa sakit, meningkatkan permeabilitas kapiler, memberikan kehangatan pada tubuh sehingga sangat bermanfaat untuk terapi penurunan tekanan darah pada hipertensi [13].

Pada tekanan diastole keadaan di dalam ventrikel turun drastik dan aliran darah menjadi lancer dengan adanya pelebaran pembuluh darah dapat menurunkan tekanan darah diastolic, Dalam hal ini, terapi air hangat dapat mengurangi tahanan perifer, Penurunan tekanan darah juga dapat terjadi akibat berkurangnya aktivitas jantung memompa darah. Peningkatan efisiensi kerja jantung dicerminkan dengan penurunan tekanan darah sedangkan penurunan tahanan perifer dicerminkan dengan penurunan tekanan diastolik. Secara psikologis respon tubuh terhadap air hangat dimana terjadi perpindahan hangatnya air ke tubuh dapat menghilangkan stress, kegelisahan, depresi, kecemasan sehingga membuat perasaan menjadi rileks, tenang dan nyaman. Namun terapi ini tidak dianjurkan bagi penderita diabetes mellitus dikarenakan karena akan mengakibatkan kulit penderita menjadi rusak[14].

\section{Kesimpulan}

Dari hasil analisa literature review terhadap ketiga jurnal dapat disimpulkan persamaan hasil dari terapi ada perbedaan tekanan darah sistolik dan diastolic sebelum dan setelah. Namun demikian literature review ini menunjukan bahwa terapi komplementer memiliki peranan penting dalam pengobatan traditional sebagai terapi non farmakologi.Terapi komplementer memiliki efek samping yang aman dibandingkan dengan efek samping dari reaksi obat kimia. 


\section{Prosiding Seminar Nasional Kesehatan 2021 \\ Lembaga Penelitian dan Pengabdian Masyarakat Universitas Muhammadiyah Pekajangan Pekalongan}

\section{Referensi}

[1] Ardiansyah,M.J.J.E. Keperawatan medical bedah. (2012).

[2] Triyanto, E. J. Y. G. I. Pelayanan keperawatan bagi penderita hipertensi secara terpadu. (2014).

[3] Martono, H., \&Pranaka, K. Buku Ajar Boedhi-DarmojoGeiatri (Ilmu Kesehatan Lanjut Usia). In:Edisike. (2009).

[4] Ardiansyah,M.J.J.E. Keperawatan medical bedah. (2012).

[5] Aquino, G. d. A., Cruz, D. T. d., Silvério, M. S., Vieira, M. d. T., Bastos, R. R., \& Leite, I. C. G. J. R. B. d. G. e. G. Factors associated with adherence to pharmacological treatment among elderly persons using antihypertensive drugs. 20(1), 111-122. (2017).

[6] Asan, Y. J. C. H. J. PerbedaanTekanan Darah Sebelum Dan Sesudah Terapi Rendam Kaki Air Hangat Pada Lansia Di Upt Panti Sosial Penyantunan Lanjut Usia Budi Agung Kupang. 1(1). (2016).

[7] Harnani, Y., \& Axmalia, A. J. P. J. K. K. Terapi Rendam Kaki Menggunakan Air hangat Efektif Menurunkan Tekanan Darah Pada Lanjut Usia. 3(4), 129-132. (2017).

[8] Solechah, N., Masi, G., \& Rottie, J. J. E. K., 05. Pengaruh Terapi Rendam Ka i Air Hangat Terhadap Penurunan Te anan Darah pada Pasien dengan Hipertensi di Pus esmas Bahu Manado. (2017).

[9] Wenny, R. M. Pengaruh Berjalan Kaki Dan Hidroterapi Rendam Kaki Air Hangat Terhadap Penurunan Tekanan Darah Pada Lansia Hipertensi Di Uptd Griya Werdha Surabaya. Universitas Airlangga. (2019).

[10] Lalage, Z. Hidup sehat dengan terapi air. (2019).

[11] Solechah, N., Masi, G., \& Rottie, J. J. E. K., 05. Pengaruh Terapi Rendam Kaki Air Hangat Terhadap Penurunan Te anan Darah pada Pasien dengan Hipertensi di Pus esmas Bahu Manado. (2017).

[12] Pancawati, K. Asuhan Keperawatan Penerapan Terapi Rendam Kaki Air Hangat Terhadap Penurunan Tekanan Darah Pada Lansia Dengan Hipertensi Di Wilayah Kelurahan Tandang Kecamatan Tembalang Kota Semarang. Universitas Muhammadiyah Semarang. (2018).

[13] Santoso, D. A. J. J. P. Pengaruh Terapi Rendam Kaki Air Hangat Terhadap Penurunan Tekanan Darah Pada Lansia Penderita Hipertensi Di Wilayah Kerja UPK Puskesmas Khatulistiwa Kota Pontianak. 3(1). (2015).

[14] Wijaya, A. S., \& Putri, Y. M. KMB; Keperawatan Medikal Bedah (Keperawatan Dewasa). (2013). 